\title{
Review
}

\section{The problem with work: Feminism, Marxism, antiwork politics and postwork imaginaries}

\author{
Kathi Weeks \\ Duke University Press, Durham, NC and London, 2011, 287pp., \\ \$22.32/£15.99, ISBN: 978-0822351122 \\ Contemporary Political Theory (2013) 12, e5-e7. doi:10.1057/cpt.2012.6
}

Kathi Weeks' The Problem with Work: Feminism, Marxism, Antiwork Politics and Postwork Imaginaries is a brave, important and politically exciting book. Weeks uses her opening question, 'Why do we work so long and so hard?' to good effect (p. 1). With it, she begins a far-reaching discussion of radical political theory that is ultimately used to advance and defend the notion that we ought to demand less work and more free time, concluding with suggestions for the development of a feminist 'time movement' (p. 171). Weeks productively engages with a wide variety of theories and literature, deftly ranging from David Harvey, to Moishe Postone, to Max Weber, to Betty Friedan, to science fiction, to Marx and others too numerous to name. The extraordinary range of Weeks' scholarship is only outdone by her ability to weave those many complexities into a tapestry that concludes with an inspiring political exhortation.

Particularly exciting is Weeks' reengagement with elements of second wave and Marxist feminist theories that many may have not considered apart from the 'history of feminist theory' portion of their syllabi. For example, Weeks' return to the second wave feminist discussion of wages for housework is enlightening. The discussion of several key Marxist-feminist texts foregrounds Maria Dalla Costa's 1975 work, The Power of Women and the Subversion of Community. Weeks situates Dalla Costa in the Autonomous Marxist tradition. The effect is a revelatory reinvigoration of second wave Marxist feminist insights that re-centers the figure of the housewife as a site of gendered work and the production of subjectivity. The status of housework in Marxist feminism has always been important, though 1970's debates about it became somewhat tedious. Discussions of the differences between reproduction and production, how labor is defined as against work, what constitutes the family wage (and whether it still exists), whether or not housework is related to the production of surplus value and so on, were perhaps of questionable importance if one's interests went beyond trying to keep feminist analyses

(C) 2013 Macmillan Publishers Ltd. 1470-8914 Contemporary Political Theory Vol. 12, 2, e5-e7 www.palgrave-journals.com/cpt/ 
within the categories of a certain version of Marxist economics. Weeks' book opens up a conceptual space for a new reading of Marxist feminist concepts, and a fresh take on familiar themes, that maintains a connection to the Marxist tradition but moves away from situating housework inside Marxist economic orthodoxy.

Exemplary is her embrace of the autonomist concept of class. Marx argued that class is determined by one's position in the production process. In this way, the proletariat can be objectively known, and the political goal for this class is to know itself subjectively as a class (that is, to become class-conscious). In contrast, Weeks argues that class comes from political activism about work and thereby avoids the many problems with the labor/work distinction that had so dominated the 1970's discussion. Class, she argues, is an outcome of activism, not a cause. This revised theory of radical agency gets rid of several problems in Marxism and Marxist feminism. The problem of classconsciousness is gone. If class is constructed around activism about work (and not around labor), then one need not wait for the class to become conscious of itself. A class is constituted when it is acting as a class. Thus, freed from older conceptualizations of class, activism around gendered conditions of work is more easily conceptualized as class activity, and the conceptual problems with which Dalla Costa and others grappled diminish or vanish altogether.

Weeks concludes that the demand for wages for housework is wrongheaded in that it interpellates women into capitalism by linking work to survival and wages. Her suggestion is to change the narrative entirely. Weeks suggests that as the figure of the housewife is the quintessential example of gendered work, it provides an opportunity for an analysis of how work genders us.

In this way, the politics of housework is linked to the politics of work overall, and the position Weeks advocates is not that we demand wages for work, but that we refuse work outright. She suggests this politics of anti-work as a utopian strategy rather than a demand. Weeks argues that such a politics would acknowledge, as Postone has argued, that work is the "primary means by which individuals are integrated not only into the economic system, but also into social, political and familial modes of cooperation' (p. 8). Declining to work would follow Marxism in that it would shift the activism back to the point of production and away from consumer-based strategies such as ethical buying. She argues that such a politics has the potential to repoliticize work by challenging both the work ethic and the 'work society' (p. 5). It would denaturalize waged work, and expose it as a central mechanism of the reproduction of capitalism.

Citing Postone, Weeks argues that work is the primary means by which individuals are integrated into the economic system, socio-political and family modes of cooperation. That individuals should work is fundamental to this model of social contract. Moreover, workers are expected to do gender at 
work. Feminism has participated in the mystification and moralization of work in arguing that waged work would be women's ticket out of domesticity. Weeks' advocacy of a politics of refusal would advocate a liberation from work, and a move into what she calls a 'postwork society' (p. 227).

Weeks uses the work of Ernst Bloch to great effect in discussing what she means by utopian politics. Bloch and the Frankfurt school used the idea of utopia not as Thomas More did (that is, to mean 'nowhere'), but rather to mean a space of alterity and desire where the subject is not wholly colonized by the logics of capitalism and fascism. Her reference to Bloch clearly accomplishes her goal of building an argument about utopian possibility and hope, and it reminds us that there is a space of resistance in the imaginary that is both practical and necessary. Weeks re-reads these texts (as well as others, such as Weber and Baudrillard) in light of her own project. The book is something of a fantastical tour of post nineteenth century radical politics and theory. It is a book that demands reading and re-reading, as much for its new readings of old theories as for its useful appropriation of autonomous Marxism for feminist theory. Weeks' exciting suggestions about a politics of time and leisure directly connect theory to activism in this inspiring and intellectually engaging text.

Judith Grant

Ohio University Athens OH 45701, USA 